Roger Williams University

DOCS@RWU

$5-9-2012$

\title{
Life Without Parole: The Influence of Age and Race on the Sentencing of Juvenile Offenders
}

Maria Annabel Mireles

Roger Williams University, mmireles236@g.rwu.edu

Follow this and additional works at: https://docs.rwu.edu/psych_thesis

Part of the Psychology Commons

\section{Recommended Citation}

Mireles, Maria Annabel, "Life Without Parole: The Influence of Age and Race on the Sentencing of Juvenile Offenders" (2012). Psychology Theses. 9.

https://docs.rwu.edu/psych_thesis/9

This Thesis is brought to you for free and open access by the Arts and Sciences Theses at DOCS@RWU. It has been accepted for inclusion in Psychology Theses by an authorized administrator of DOCS@RWU. For more information, please contact mwu@rwu.edu. 
Running head: LIFE SENTENCES WITHOUT PAROLE FOR JUVENILES

Life Without Parole: The Influence of Age and Race on the Sentencing of Juvenile Offenders

Maria Annabel Mireles

Master of Arts

Forensic Psychology

Feinstein College of Arts and Sciences

Roger Williams University

May 2012 


\section{ROGER WILLIAMS UNIVERSITY \\ GRADUATE PROGRAM IN FORENSIC PSYCHOLOGY \\ THESIS PROJECT FORM}

Date: $10 / 19 / 11$

To: (1) Dean, College of Arts and Sciences - 2 copies

(2) Thesis Chair - 1 copy

(3) Student - 1 copy

(4) Departmental File - 1 copy

Approval is given to:

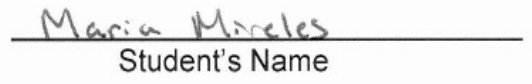

0812333

ID \#

a candidate for degree of Master of Arts in FORENSIC PSYCHOLOGY, to use the following thesis topic:

Life Without Parole: The Influence of Age and Rass on the Seateneng of Juvenite Offenders

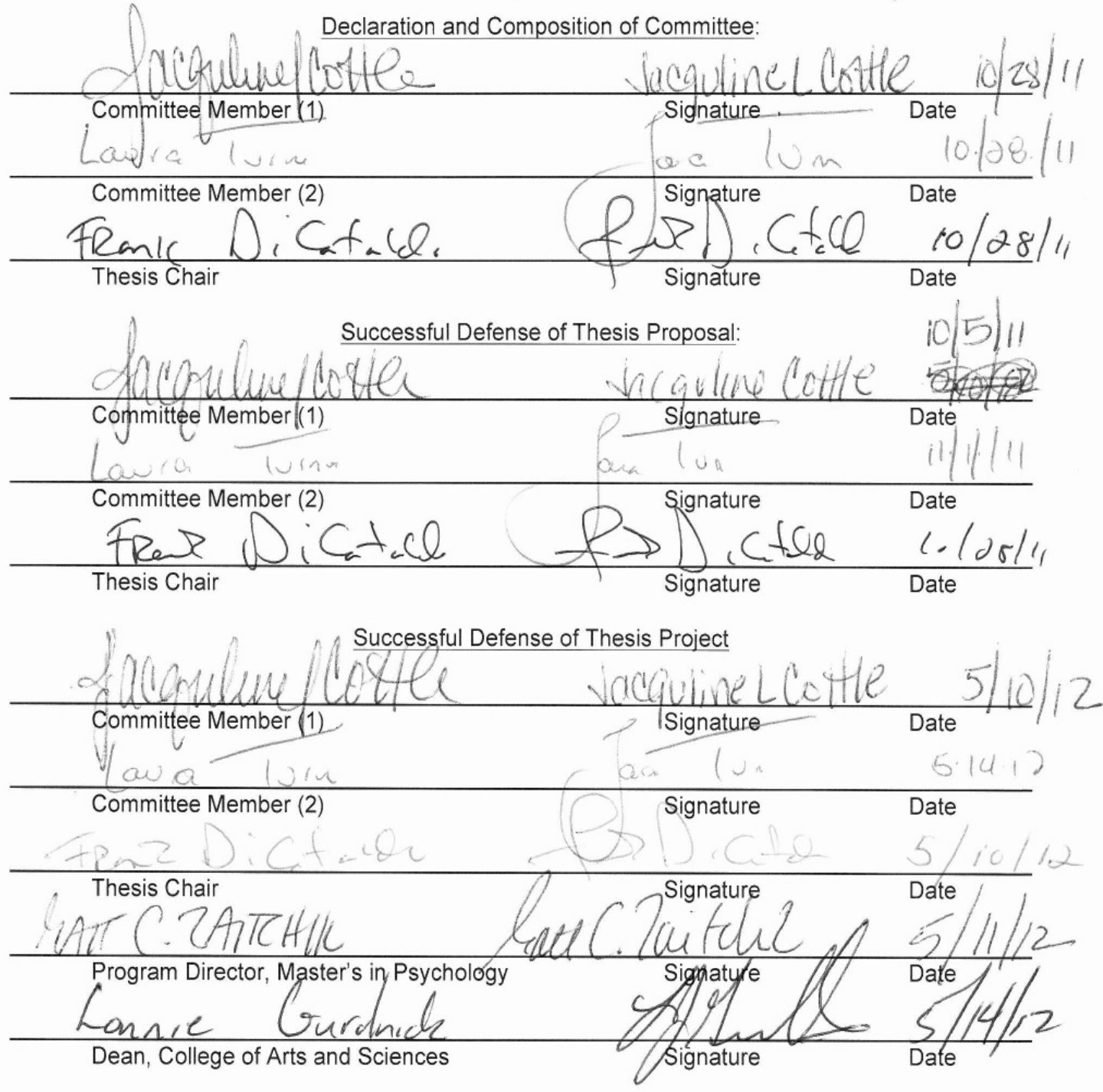




\section{Acknowledgements}

I would like to thank my thesis committee, Dr. Frank Dicataldo, Dr. Jacquline Cottle, and Dr. Laura Turner for all of their assistance and hard work. A special thank you to Dr. Judith Platania for her insights into the world of statistics and data analyses. I could not have done this without you all. 


\begin{abstract}
In 2010, the Supreme Court ruled it unconstitutional to sentence adolescents charged with nonhomicide crimes to life without parole (Graham v. Florida, 2012). Currently, research regarding life without parole is assessed in conjunction with the death penalty, in which life without parole is proposed as a lesser alternative to the death penalty. The current study investigated whether age and race are predictive factors in sentencing juvenile offenders. A sample consisting of 225 undergraduate students were presented with one of six case scenarios adapted from Wilkins $v$. Missouri (1985) in which the defendant's age $(13,15,17)$ and race (Caucasian, African American) were varied. Thirteen-year-old defendants were significantly more likely to receive a less severe alternative sentence to life without parole. Furthermore, African American defendants were significantly more likely to receive more severe sentences. These findings provide implications for changes in current policy and jury selection processes.
\end{abstract}


Life Without Parole: The Influence of Age and Race on the Sentencing of Juvenile Offenders

The juvenile court was founded on two principles: adolescents are less culpable by reason of diminished capacity for mature judgment, and have a greater propensity towards rehabilitation (Cauffman \& Steinberg, 2000). While the United States has recognized the need to distinguish juvenile offenders from adult offenders, the U.S. remains one of the only countries to allow adolescents to be sentenced to life without the possibility of parole (Pifer, 2010). In the past few decades changes in policy have blurred the line distinguishing adolescents from adults by making it easier to transfer and try adolescents in adult court, yet landmark cases establishing limits on sentencing juvenile offenders have continued to cite developmental differences between adolescents and adults in support of their rulings (Thompson v. Oklahoma, 1988; Roper v. Simmons, 2005; Graham v. Florida, 2010)

Thompson v. Oklahoma (1988) marked the first ruling against the application of a categorical punishment on a specific population (i.e. adolescents). As a measure of the advancement of a developing nation, Trop v. Dulles (1958) established the need for courts to consider the "evolving standards of decency" when considering whether a punishment is constitutional or unconstitutional (p. 101). Therefore, in determining the constitutionality of sentencing youth to the death penalty, the Supreme Court ruled that the evolving standards of decency require that an age be determined below which an individual cannot be sentenced to death (Thompson v. Oklahoma, 1988). While the decision of the Court was primarily based on legislative precedence, the court acknowledged the issue of age-related immaturity differentiating adolescents from adults. Therefore, the Court ruled the death penalty unconstitutional for adolescents aged 15 and younger. In establishing this age limit the Court 
stated that they could not determine whether all adolescents suffered the same levels of diminished capacity.

In 2005, the Supreme Court's ruling in Roper v. Simmons extended the Thompson (1988) ruling, declaring that imposing the death penalty on offenders who committed their crimes before age 18 violated Eighth Amendment rights against cruel and unusual punishment (Roper v. Simmons, 2005). In Roper v. Simmons (2005) the Court addressed several mitigating factors influencing the decisions to constitute a punishment as cruel and unusual. Among these factors are the influences of age and development on the culpability of juvenile offenders.

In Roper (2005), the Court determined that juveniles are "inherently immature," more susceptible than adults to peer influences and more impulsive. For these reasons, the Court argued that adolescents are less culpable than their adult counterparts. Furthermore, the Court determined that developmental differences suggest that adolescents have not fully developed their personalities, and as such they have a greater propensity for change (Roper $v$. Simmons, 2005). The Court further argued that sentencing adolescents to death prevents them from gaining a well-developed understanding of their own mortality. Additionally, the Court determined that diminished capacity of adolescents makes them less susceptible to deterrence, one of the primary arguments supporting the utilization of the death penalty (Roper v. Simmons, 2005).

The arguments addressing reduced culpability of adolescents in Roper (2005) were also used to support a change in the implementation of life sentences without parole on juvenile offenders (Graham v. Florida, 2010). In 2010, the Supreme Court ruled it unconstitutional to sentence adolescents charged with non-homicide crimes to life without parole (Graham v. Florida, 2010). This decision marked the first ruling of a categorical punishment, other than the death penalty, as unconstitutional (Pifer, 2010). In making their decision, the Court cited 
research supporting the issues of adolescents' increased risk taking behaviors, reduced inclinations to assess cost-benefit analyses and consideration of long-term consequences in decision-making, and continued brain development into early adulthood as an explanation for adolescents having reduced impulse control. The Court also acknowledged a juvenile's susceptibility to peer influences as supporting the notion of reduced culpability (Graham v. Florida, 2010). Despite acknowledging the reduced capacities of adolescents, the Court reserved the right to sentence juveniles convicted of homicide to life without the possibility of parole (Graham v. Florida, 2010).

Advocates for children's rights suggest that the arguments used in both Roper (2005) and Graham (2010) should be extended to rule life sentences without parole unconstitutional for all offenders who commit any type of crime, including homicide, before age 18 (Pifer, 2010). However, before a sentence may be ruled unconstitutional several factors must be considered including current implementation of the punishment, adolescent development, and international law.

\section{U.S Policy for Life Without Parole for Adolescent Offenders}

Currently, 42 states, the District of Columbia, and the Federal Government allow the imposition of life sentences without parole on juvenile offenders (Pifer, 2010). Among the eight states that prohibit imposing this sentence on juveniles, five have abolished life without parole for all offenders (Ogilvie, 2008; see also Human Rights Watch \& Amnesty International, 2005). Although the majority of states permit the sentencing of juveniles to life without parole, standards vary regarding its application (Pifer, 2010). In 27 of the 42 states, sentences of without parole are mandatory for specific crimes including homicide and felony-murders regardless of an offender's age (Massey, 2006; see also Human Rights Watch \& Amnesty International, 2005). 
States with mandatory sentences have significantly higher rates of adolescents serving life without parole compared to states exercising the use of discretionary sentencing (Human Rights Watch \& Amnesty International, 2005). Discretionary sentencing allows judges the opportunity to consider mitigating circumstances, including the defendant's age, mental capacity, and criminal history to ascertain an appropriate sentence for the offender. Mandatory sentencing prevents the consideration of these mitigating factors in determining sentencing (Massey, 2006). Approximately 59\% of juvenile offenders currently serving life without parole received this sentence for their first criminal conviction (Human Rights Watch \& Amnesty International, 2005). Thus some adolescents, who have never been previously convicted of a crime, are receiving the maximum sentence available to impose on a juvenile offender.

Currently, 2,574 inmates serving sentences of life without parole were convicted for crimes committed before age 18 (Pifer, 2010), and of these offenders, 29\% entered prison before age 18 (Human Rights Watch \& Amnesty International, 2005). States supporting sentencing juveniles to life without parole also have a limited consensus regarding the minimum age at which an adolescent may receive the sentence (Ogilvie, 2008). Minimum age limits range from 8 to 16 years of age, with several states having no minimum age restrictions (Ogilvie, 2008). Although age restrictions vary, the average age of conviction for juvenile offenders presently serving life sentences without parole is above 15 years (Human Rights Watch \& Amnesty International, 2005).

In order to address the varying standards of implementing sentences of life without parole, researchers suggest a need for discretionary sentencing and more consistent minimum age limits (Ogilvie, 2008). Furthermore, in determining adolescent culpability and appropriate 
sentences, the courts and policymakers alike must consider the developmental differences between adolescents and adults (Massey, 2006).

\section{Adolescent Development}

The issue of adolescent development and culpability has been continuously debated long before the establishment of the juvenile justice system (Cauffman \& Steinberg, 2000). Two of the primary issues surrounding youth development and the legal system pertain to judgment and decision-making abilities (Cauffman \& Steinberg, 2000; Steinberg \& Scott, 2003). Researchers have found differences in both neurological and psychosocial development between adolescents and adults indicating that adolescents do not function at the same level as adults (Luna, Garver, Urban, Lazar \& Sweeney, 2004; Steinberg et al., 2009; Steinberg \& Scott, 2003).

Neurological development. Through various studies on brain development and cognition, research has found that adolescents demonstrate reduced capacities in cognitive processing well into late adolescence and early adulthood (Aronson, 2007; Caulum, 2007; Luna et al., 2004). Neurological studies have shown that the brain continues to develop during adolescence into early adulthood; more specifically the striatal lobe and the frontal lobe of the prefrontal cortex are the last areas to develop within the brain (Aronson, 2007). While both the striatal and frontal lobes affect cognitive processes, the frontal lobe is primarily responsible for major executive functioning including judgment, reasoning, long-term planning, and impulse control (Steinberg et al., 2009). According to Steinberg (2007), the prefrontal cortex undergoes a gradual growth over an extended period of time, which continues into early adulthood. Part of this growth involves an integration of neural pathways from the prefrontal cortex into other regions of the brain, providing increased control of cognitive responses (Steinberg, 2007). 
Since the frontal lobe is the last region to develop, the adolescent brain must compensate for this underdevelopment by using other regions of the brain to process information normally processed through the frontal lobe. Whereas adults process certain information using the frontal lobe (e.g. facial expressions and recognition), it has been found that adolescents process this same information through the amygdala, which is responsible for interpreting emotion, assessing danger, and eliciting fear responses (Aronson, 2007). Research has shown that processing this information through the amygdala contributes to the misinterpretation of information (Baird et al., 1999). For example, Baird et al. (1999) found that adolescents were more likely to misidentify facial expressions compared to adults in which fearful expressions were often characterized as angry, confused, or surprised. These findings are important considering that misinterpreting a fearful expression for an angry or surprised expression will impact how an individual will react in a given situation. Additionally, researchers have found that compared to adults, the adolescent's underdeveloped frontal lobe does not modulate neurotransmissions from the amygdala, a process which allows for more conscious appraisals of situations (Hariri, Mattay, Tessitore, Fera, \& Weinberger, 2003).

Psychosocial development. In addition to neurological differences, significant differences have been found in psychosocial development of adolescents compared with that of adults (Steinberg \& Scott, 2003). According to Steinberg and Scott (2003), assessment of these differences within legal contexts has primarily focused on judgment and decision-making. Steinberg and Scott (2003) also suggest that while neurological capacities influence the processes by which judgments and decisions are made, psychosocial factors affect the outcomes. Among the most influential psychosocial factors contributing to adolescent judgment and 
decision-making are susceptibility to peer influences, risk assessment, and future orientation (Steinberg \& Scott, 2003).

Research provides substantial support for the argument that adolescents are more strongly subject to peer influences than adults. Researchers have found that adolescent judgment is both directly and indirectly affected by peer influences (Moffitt, 1993; Steinberg \& Scott, 2003). According to Moffitt (1993), adolescents are more likely to modify their behavior to conform to what is socially acceptable when in the presence of peers. Moffitt (1993) also suggested that adolescents believed modeling the behavior of their peers would aid them in accomplishing their goals. Furthermore, the desire for peer approval and the fear of rejection continues to influence adolescents and their choices, even when not in the presence of peers (Moffitt, 1993). Research has shown that when presented with a situation, adolescents are more likely to choose a solution that is supported or suggested by peers, even if the solution may have negative consequences or their peers are not present at the time the decision is made (Steinberg and Scott, 2003).

Additionally, susceptibility to peer influences has been found to peaks around age 14 and slowly decrease through late adolescence (Steinberg and Scott, 2003).

In accordance with neurological development, adolescents show marked impairment in their orientation towards the future. Studies have shown that compared to adults, adolescents are significantly more likely to consider short term rather than long term effects in their decision making. These differences have been attributed to both neurological development and limited life experiences (Steinberg \& Scott, 2003). Cauffman and Steinberg (2000) found that age significantly influenced one's propensity to consider their future as part of decision making, with consideration of the future increasing with age. Similarly, Steinberg et al. (2009) found that when analyzing adolescents' tendencies for planning ahead, skewed perceptions of time, and 
anticipation of future consequences, adolescents scored significantly lower than adults in all three categories. The researchers also found that while adolescents displayed some elements of planning around age 10, there was a significant decline in planning between ages 10 and 15, followed by a gradual increase in planning after age 15 (Steinberg et al., 2009).

As part of future orientation, researchers have also found that adolescents act based on a risk-reward system. According to Steinberg and Scott (2003), psychosocial factors are more influential in adolescent decision-making than with adults. Adolescents tend to place greater emphasis on potential rewards than they do on potential risks associated with their decisions and actions (Steinberg \& Scott, 2003). Steinberg and Scott (2003) suggest that adolescents have a more time limited perspective in which risks are perceived as less relevant to immediate situations. Differences in short term versus long term goals may also influence whether one perceives a behavior or choice as providing either a reward or a risk (Steinberg \& Scott, 2003). For instance, Steinberg et al. (2009) found younger adolescents, aged 13 and younger, were more likely than adolescents aged 16 and older to accept smaller rewards in order to receive them immediately rather than larger delayed rewards. Cauffman and Steinberg (2000) explain increased risk taking and reward seeking behavior in adolescents as an interaction effect between psychosocial factors and cognitive development.

\section{Public Opinion of Life without Parole}

In Coker v. Georgia (1977), the Supreme Court declared that public judgment and the evolving standards of decency strongly influence whether a sentence can be ruled disproportionate for a crime or population (e.g. juveniles). Therefore, before making its decision in Roper (2005), the Supreme Court addressed the importance of determining community 
sentiments toward current law (Finkel, Hughes, Smith, \& Hurabiell, 1994). Public sentiment was determined to be based on current state legislature along with jury sentencing practices.

While an abundance of research has been conducted regarding public opinion and the death penalty for special populations, less research has been conducted to assess public sentiment towards sentencing juveniles to life without parole (Kubiak \& Allen, 2008). The studies that have addressed public opinion of life without parole for juveniles have primarily been assessed in conjunction with death penalty research, in which life without parole serves as an alternative sentence (Kubiak \& Allen, 2008; Vogel \& Vogel, 2003). When presented as an alternative to the death penalty, Vogel and Vogel (2003) found that of the individuals who opposed the death penalty, only $25 \%$ also opposed life sentences without parole for juveniles, and $58.5 \%$ supported life without parole as an alternative sentence to the death penalty. Kubiak and Allen (2008) conducted a public opinion poll in which they assessed whether the general public supported Michigan's current policy regarding sentencing juveniles to life without parole, and whether individuals would act in accordance with Michigan's policy of mandatory life sentences if given the opportunity to consider alternatives. The researchers found that whereas $42.6 \%$ of individuals agreed with Michigan's policy, when presented with alternative sentences, only $8.5 \%$ who agreed with current policy chose to act in accordance with the law and sentence a juvenile to life without parole (Kubiak \& Allen, 2008). On the other hand $60.6 \%$ of individuals who stated they agreed with current policy chose a less severe alternative sentence to life without parole (Kubiak \& Allen, 2008).

\section{Assessing Public Opinion}

Although public opinion polls may address perceptions of sentencing juveniles with the death penalty or to life without parole, they primarily present individuals with generalized 
stimuli or ask limited response questions (Kubiak \& Allen, 2008). For instance, previous studies have asked whether the respondent agrees or disagrees with sentencing a juvenile to life without parole, how strongly they agree or disagree, or for what categories of crimes or age groups would a life sentence be appropriate (Kubiak \& Allen, 2008; Vogel \& Vogel, 20003; Finkel, Hughes, Smith, \& Hurabiell, 1994). Limited research has assessed community sentiment when presented with specified information, requiring individuals to decide the sentence of a particular juvenile offender.

Finkel et al. (1994) conducted an experiment to assess the community's stance on juvenile death penalty cases. In the first of a two-part study, the researchers were interested in assessing whether the perceived heinousness of a crime would outweigh the effects of age in sentencing a juvenile with the death penalty (Finkel et al., 1994). In addition to heinousness of the crime, the age of the defendant was varied. The ages of the defendants were presented as 15 , 16 , or 17 , as compared with two adults aged 18 or 25 . After being presented with a case, participants were required to choose between sentencing the offender to death or life without parole. Participants were then asked to provide the reasons for their sentencing decision. The researchers found an inverse relationship between heinousness of a crime and age, in which increases in heinousness decreased the significance of age (Finkel et al., 1994).

Based on the results from the first part of the study, Finkel et al. (1994) used the crime that participants judged as most heinous and yielded the highest rates of sentencing defendants to death. The researchers were interested in assessing whether the defendant's role in a crime (i.e. principal murderer, accessory murderer, or felony-murder accessory) would affect the death sentence rates found in the first experiment, whether there was an age effect, and if there would be an interaction effect between type of defendant and age. The researchers also increased the 
range of the defendant's age from 13 to 18, and 25. Again, participants were required to choose between the death penalty and a life sentence without parole followed by the reasoning for their decision (Finkel et al., 1994). The researchers found that juveniles who were accused of murder were more likely to be found guilty than those accused of lesser crimes, and older offenders were more likely to receive the death penalty compared to their younger counterparts (Finkel et al., 1994) They also found that when deciding sentencing, approximately $25 \%$ of young adolescents aged 13 to $15,35 \%$ of older adolescents aged 16 to 18 , and $60 \%$ of adults aged 25 were sentenced with the death penalty. The researchers found that younger adolescents were least likely to receive a death sentence, and adults were most likely to be sentenced to death (Finkel et al., 1994).

\section{Race and Offender Sentencing}

Along with age being a predictive factor in sentencing, researchers have found a defendant's race significantly influences whether they are sentenced to life without parole compared to a lesser sentence (Jordan \& Freiburger, 2010). Several researchers have assessed the effects of race on offender sentencing (Jordan \& Freiburger, 2010; Steffensmeier \& Demuth, 2006; Steffensmeier, Ulmer, \& Kramer, 1998). Eigen (1981) found that the victim's race significantly contributed to whether a defendant received a life sentence or the death penalty, compared to a lesser sentence. He found that African American offenders convicted of felonymurder were more likely to receive the death penalty or a life sentence when his victim was Caucasian compared to when the victim was of the same race (Eigen, 1981). In his study assessing the influence of race and offender's role on adolescent sentencing, Eigen (1981) found the effects of the offender's role in a crime were significantly reduced when the victim's race was presented. He found that regardless of the defendant's role in a crime, African Americans 
with victims of another race were more likely to receive harsher sentences than offenders whose victims were of their own race (Eigen, 1981). While Steffensmeier et al.'s (1998) study assessed the influence of race in the sentencing of adult offenders, they had similar findings in which young African American males were more likely to receive harsher sentences than Caucasians. The researchers also found race was most influential in the sentencing of younger offenders rather than older offenders (Steffensmeier et al., 1998). Steffensmeier and Demuth (2006) also found that African American defendants received the longest sentences compared to Caucasians and Hispanics. In a study assessing the effects of race on juvenile sentencing in adult court, Jordan and Freiburger (2010) found that African Americans and Hispanics were significantly more likely to receive a longer, prison sentence over a shorter, jail sentence, or probation. Similarly they found that Caucasian defendants were significantly more likely to receive probation as opposed to African American defendants when charged with the same crime (Jordan \& Freiburger, 2010).

Further research has had similar findings of offender race influencing adolescent's likelihood of being sentenced to life without parole. African American adolescents have been found to be ten times more likely to receive a life sentence than their Caucasian counterparts (Pifer, 2010; see also Human Rights Watch \& Amnesty International, 2005). Of the current juvenile offenders serving life without parole, $60 \%$ of the population is African American compared to $29 \%$ who are Caucasian (Ogilvie, 2008; see also Human Rights Watch \& Amnesty International, 2005). However, limited research has been conducted regarding the interaction effects of race and age on sentencing juveniles to life without parole. 


\section{Current Study}

Currently, research regarding life without parole is in conjunction with assessments of the death penalty, in which life sentences without parole are proposed as a lesser alternative to sentencing an adolescent to death (Finkel et al., 1994). Since the Roper (2005) ruling, limited studies have assessed predictive factors in sentencing adolescents now that life without the possibility of parole has become the harshest punishment available to juvenile offenders.

Stemming from the Finkel et al. (1994) study, the current study investigated the influences of both age and race on the implementation of sentences of life without parole on adolescent offenders. Based on the findings of previous studies, it was hypothesized that younger adolescents would be the least likely to receive a sentence of life without parole compared to their older counterparts. Similarly, it was hypothesized that African American juvenile offenders would be more likely to be sentenced to life without parole compared to Caucasian juvenile offenders. Furthermore, it was hypothesized that older, African American adolescents would be most likely to receive the most severe sentences while younger, Caucasian juvenile offenders would be the most likely to receive less severe sentences.

\section{Methods}

\section{Participants}

Participants were recruited from Roger Williams University through the online psychology research participation website, SONA, by which students voluntarily sign up to participate in research studies for which they receive course credits. Two hundred and thirty three subjects participated in the study. However, three subjects were excluded from the final data set due to missing data, making the sample size 230 participants. The sample was $66 \%$ female and $34 \%$ male. Ages ranged from 18 to 26 with 19.3 years $(\mathrm{SD}=1.24)$ as the average age 
of participants. The sample population was predominantly Caucasian (91\%) with the remaining 9\% of the sample comprised of Hispanic, Asian, African American, Native American, and Middle Eastern participants. A total of $15.7 \%$ of participants had been called for jury duty at least once, but $99 \%$ of participants had never served on a jury.

\section{Materials \& Procedure}

Data was collected in classrooms of the participating university. Participants were given written and verbal explanations of the study along with an assurance of confidentiality of their responses. In accordance with the Finkel et al. (1994) study, participants were randomly provided with one of six versions of a criminal case. The case was based on Wilkins v. Missouri (1989) in which an adolescent male was charged with committing a violent felony homicide. The defendant entered a convenience store with an accomplice who held down the female store clerk while the defendant stabbed her multiple times in the chest and neck. They then took money from the register and left the clerk on the floor to die. This case was chosen based on the Finkel et al. (1994) study in which this case was found to elicit the highest rate of death sentences for juvenile offenders. Participants were presented with a case summary in which the age $(13,15$, and 17) and race (Caucasian, African American) of the defendant was modified. All other details of the case remained identical and included the charge against the defendant, characteristics of the victim, and a description of the incident.

Based on the information provided the participants were required to reach a verdict of guilty or not guilty. Since the purpose of the study was to investigate sentencing of juveniles, participants were expected to perceive the defendant as guilty. Participants were then required to determine one of five possible sentences (20-25 years, 25 years to life, Life with Parole, Life without Parole, or no sentence if found not guilty). Participants were asked to rate on a scale 
from 1 to 10 the level of confidence supporting their choice of verdict and sentence. Following collection of the response sheets, participants filled out a questionnaire, reporting their gender, age, and race. To determine if participants had prior exposure to the jury system participants also reported whether they had ever been called for jury duty and if they ever served on a jury. Finally, participants were debriefed in which they were told that the current study was investigating whether age and race are predictive factors in adolescent sentencing and were asked not to discuss the purpose of the study with anyone so as not to compromise data from potential participants.

\section{Results}

The current study examines the predictive ability of age and race on sentencing judgments. The first parameter of the study was to ensure that participants believed the defendant was guilty. Five participants found the defendant not guilty, indicating that $97.8 \%$ of participants believed the defendant was guilty. A crosstabs for verdict by sentence was conducted to determine if the participants who believed the defendant to be not guilty were also the participants who chose no sentence for the defendant. Since the primary objective of the study was to examine sentencing of adolescent offenders, the same five participants who found the defendant not guilty chose no sentence for the defendant, therefore they were excluded from the final data set, making the final sample size 225 participants.

Variance in participants' confidence ratings for their verdict and sentencing decisions was assessed using confidence percentage ratings. Over $91 \%$ of participants rated the confidence in their verdict decisions as 7 or higher on the 10 point confidence rating scale. Similarly, over $79 \%$ of participants rated the confidence in their sentencing decisions as 7 or higher on the 10 point confidence rating scale. Since the confidence ratings in both verdict and sentencing 
decisions were not equally distributed, but rather heavily skewed towards completely confident, they were not used in further analyses.

Due to constraints with the data, analyses investigating the interaction effects of age and race on sentencing could not be conducted. An ordinal regression, or PLUM (Polytomous Universal Model) was performed to assess the impact of a defendant's age and race on the likelihood that respondents would attribute more severe sentences to defendants. The full model containing both predictors was statistically significant, $\chi^{2}(3, \mathrm{~N}=225)=77.63, p=.002$, indicating that the predictors as a set were able to distinguish the severity of sentences imposed on defendants. The model as a whole explained 6.4\% (Cox and Snell Pseudo R-square) of the variance in sentence severity. Both age and race made a unique statistically significant contribution to the model.

According to the Wald criterion for age, 13 year old defendants predicted sentence severity, $z=9.16, p=.002$. As illustrated in Figure 1, 13 year old defendants were significantly more likely to be sentenced to 20 to 25 years and 25 years to life while 17 year old defendants were more likely to be sentenced to life without parole. Of all defendants sentenced, $12.4 \%$ were 13 years old and sentenced to 25 years to life. As shown in Table 1, 45.9\% of all defendants who received a sentence of 25 years to life were 13 years old, and $41.8 \%$ of all defendants who received a life sentence without parole were 17 years old. As depicted in Figure 2, as sentence severity increased, percentage of 13 year old defendants receiving each sentence decreased while the percentage of 17 year old defendants receiving each sentence increased.

In addition, race was found to significantly predict sentence severity according to the Wald criterion, $z=4.43, p=.035$. As illustrated in Figure 3, Caucasian defendants were significantly more likely to receive sentences of 25 years to life or life with parole. Of all 
defendants sentenced 24\% were African American and sentenced to life without parole compared to only $16.4 \%$ of defendants who were Caucasian and sentenced to life without parole. As shown in Table 2, 59.3\% of defendants sentenced to life without parole were African American compared to $40.7 \%$ who were Caucasian. Depicted in Figure 4, as sentence severity increased from 25 years to life to life without parole, percentage of African American defendants receiving each sentence increased while percentage of Caucasian defendants receiving each sentence decreased.

\section{Discussion}

The current study examined the influence of defendant age and race on the sentencing of juvenile offenders. Past research on juvenile sentencing has used life without parole as a lesser alternative to the death penalty, in which adolescents were more likely to receive life without parole (Finkel et al., 1994; Kubiak \& Allen, 2008; Vogel \& Vogel, 2003). Given research on capital punishment demonstrating that young adolescents are least likely to receive death sentences, and changes in current law regarding sentencing adolescents to life without parole, the question was posed as to whether the same sentencing practices would carry over now that the cap for sentencing juveniles is life without parole.

Results from the current study indicated that with life without parole as the most severe sentence available, 13 year old defendants are more likely to be sentenced to lesser alternatives than life without parole. Participants were most likely to sentence 13 year old defendants to 20 to 25 years or 25 years to life while 17 year old defendants were more likely to receive sentences of life without parole. These findings suggest that age is a significant factor in juvenile sentencing. When given the option, this study demonstrated that people are more likely to choose a less severe alternative to life without parole for young adolescent defendants. However, given that 
$50 \%$ of 17 year old defendants were sentenced to life without parole indicates that there still remains support for sentencing youth to life without parole.

In contrast to findings from Finkel et al.'s (1994) study in which 15 and 16 year old defendants were significantly less likely to receive the death penalty, this study did not find 15 year old defendants were predictors for sentencing decisions. However, since 15 year old defendants were not significantly more likely to be sentenced to life without parole or more likely to receive lesser alternatives, more research is needed to further assess differences in sentencing decisions for adolescent offenders.

Research investigating race as a predictive factor for sentencing has generally investigated the interaction effect between the race of the defendant and the race of the victim in which Caucasian defendants charged with murdering a victim of the same race are significantly more likely to receive a lesser sentence compared to Caucasian defendants with African American victims and African American defendants overall (Eigen, 1981; Steffensmeier et al., 1988; Steffensmeier \& Demuth, 2006). Moreover, African American defendants convicted of murdering a Caucasian individual are significantly more likely to receive the harshest sentence available compared to any other offender (ForsterLee, ForsterLee, Horowitz, and King, 2006; Steffensmeier et al., 1988; Steffensmeier \& Demuth, 2006). While the race of a victim has been shown to influence sentencing decisions, the current study demonstrates that even with the absence of victim race, African American defendants are significantly more likely to receive more severe sentences. Consistent with previous research, the current study found that participants sentenced Caucasian defendants to less severe alternatives to life without parole (ForsterLee, ForsterLee, Horowitz, and King, 2006; Jordan \& Freiburg, 2010; Steffensmeier et al., 1988; Steffensmeier \& Demuth, 2006). When charged with the same crime, African 
American defendants were significantly more likely to receive a sentence of life without parole whereas Caucasian defendants were significantly more likely to be sentenced to 25 years to life. These findings are consistent with reports from Amnesty International indicating African American adolescents are serving a sentence of life without parole at a rate 10 times greater than Caucasian defendants (Human Rights Watch \& Amnesty International, 2005).

The results from the current study provide support for changes in policy regarding the implementation of life sentences without parole on juvenile offenders. Consistent with the current sentencing practices for adolescent offenders convicted of homicide in which the average age of offenders who are sentenced to life without parole are 16 years old (Human Rights Watch \& Amnesty International, 2005), participants’ lack of willingness to sentence the youngest adolescent defendants to life without parole offers support for instituting a national minimum age limit for which adolescent offenders are eligible to receive sentences of life without parole. However, 15 year old defendants were not found to significantly predict sentencing decisions, indicating that more research is needed to investigate perceptions of defendant age among juvenile defendants aged 14 to 16 years olds. Additionally, while the majority of states practice mandatory sentencing in homicide cases, these findings support the use of discretionary sentencing in which mitigating factors such as age may be considered when sentencing young offenders charged with homicide (Massey, 2006; Human Rights Watch \& Amnesty International, 2005). Given that race is not supposed to be considered when determining a verdict or sentence for a defendant, the findings from the current study that a defendant's race is a significant factor in juror decisions, suggest a need for changes in jury selection processes. These findings suggest a need for stronger screening practices for jury selection that will specifically address the issue of juror biases regarding defendant race. 


\section{Limitations}

A primary limitation of the current study was that an interaction effect between age and race could not be analyzed. Due to the four level, ordinal dependent variable along with the strongly skewed confidence ratings for sentencing decisions, a sentencing scale (sentence X confidence rating) could not be computed that would have allowed for additional analyses investigating an interaction effect between age and race on sentencing decisions. Future studies should consider the use of a dichotomous dependent variable such as life without parole versus life with parole or another non life without parole sentence that would enable the additional analyses to be conducted.

A second limitation for this study was that the sample population was predominantly Caucasian. This lack of diversity is particularly concerning for two reasons. The first is that the sample does not adequately represent the diverse population of the United States. Secondly, it is concerning given that race was a significant factor being investigated in the current study. There was also an issue of ecological validity in which judges are primarily responsible for making sentencing decisions not jurors. However, this study was primarily interested in public support of sentencing adolescent offenders to life without parole as measured by whether individuals would be willing to impose this sentence on juveniles.

Furthermore, while significant age differences were found, the current study did not investigate the reasoning behind participant sentencing decisions. Future studies should consider having participants explain the primary reasoning behind their sentencing decision. Further studies may also want to consider including follow up questions pertaining to adolescent development or whether they believe that the defendant can be rehabilitated, and whether these beliefs may have affected their sentencing decisions. Additionally, future studies may want to 
investigate participants' understanding of sentencing procedures and their understanding of the differences between types of sentence (i.e. 25 to life, life with parole, etc).

In addition, Boots, Heide, and Cochran (2004) as well as Kubiak and Allen (2008) found that inconsistencies often arise when asking participants general questions about their support of sentencing practices, such as sentencing adolescents to life without parole, and then having them apply their sentencing beliefs to specific cases. Both studies found that participants over generalize their level of support for the death penalty and life without parole, yet demonstrate a low level of support when applying the sentencing practices to specific cases. However, this study did not investigate participants' general support for the application of life sentences without parole on juvenile offenders. Future studies should consider how the general level of support for sentencing adolescents to life without parole compare to whether individuals are willing to chose this sentence for adolescents given specific cases. This could have implications for changes in the evolving standards of decency with regards to sentences of life without parole for juvenile offenders. Additionally, these findings could have implications for whether public polls used to asses societal standards of decency accurately represent support for the implementation of life without parole on juvenile offenders. 


\section{References}

Aronson, J. D. (2007). Brain imaging, culpability and the juvenile death penalty. Psychology, Public Policy, and Law, 13, 115-142.

Baird, A. A., Gruber, S. A., Fein, D. A., Maas, L. C., Steingard, R. J, Renshaw, P. F., ... Yurgelum-Todd, D. A. (1999). Functional magnetic resonance imaging of facial affect recognition in children and adolescents. Journal of the American Academy of Child and Adolescent Psychiatry, 38, 195-199.

Boots, , D. P., Heide, K. M., \& Cochran, J. K. (2004). Death penalty support for special offender populations of legally convicted murderers: Juveniles, the mentally retarded, and the mentally incompetent. Behavioral Sciences and the Law, 22, 223-238. Doi: 10.1002/bsl.565.

Cauffman, E., \& Steinberg, L. (2000). (Im)maturity of judgment in adolescence: Why adolescents may be less culpable than adults. Behavioral Sciences and the Law, 18, 741760.

Caulum, M. S. (2007). Post adolescent brain development: A disconnect between neuroscience, emerging adults, and the corrections system. Wisconsin Law Review, 729, 730.

Coker v. Georgia, 433 U.S. 584 (1977).

Eigen, J. P. (1981). Punishing youth homicide offenders in Philadelphia. The Journal of Criminal Law and Criminology, 72, 1072-1093.

Finkel, N. J., Hughes, K. C., Smith, S. F., \& Hurabiell, M. L. (1994). Killing kids: The juvenile death penalty and community sentiment. Behavioral Sciences and the Law, 12, 5-20. 
ForsterLee, R., ForsterLee, L., Horowitz, I. A., \& King, E. (2006). The effects of defendant race, victim race, and juror gender on evidence processing in a murder trial. Behavioral Sciences and the Law, 24, 179-198.

Graham v. Florida, 560 U.S. __ (2010).

Hariri, A. R., Mattay, V. S., Tessitore, A., Fera, F., \& Weinberger, D. R. (2003). Neocortical modulation of the amygdala response to fearful stimuli. Society of Biological Psychiatry, $53,494-501$.

Human Rights Watch, \& Amnesty International (2005). The rest of their lives: Life without parole for child offenders in the United States. Retrieved from http://www.hrw.org/en/reports/2005/10/11/rest-their-lives-0

Jordan, K. L., \& Freiburger, T. L. (2010). Examining the impact of race and ethnicity on the sentencing of juveniles in the adult court. Criminal Justice Policy Review, 2, 185-201.

Kubiak, S. P., \& Allen, T. (2008). Public opinion regarding juvenile life without parole in consecutive statewide surveys. Crime \& Delinquency, doi: 10.1177/0011128708317987.

Luna, B., Garver, K. E., Urban, T. A., Lazer, N. A., \& Sweeney, J. A. (2004). Maturation of cognitive processes from late childhood to adulthood. Child Development, 75,1357-1372.

Massey, H. J. (2006). Disposing of children: The eighth amendment and juvenile life without parole after Roper. Boston College Law Review, 47, 1083-1118.

Moffitt, T. (1993). Adolescence-limited and life-course-persistent antisocial behavior: A developmental taxonomy. Psychological Review, 100, 674-701.

Ogilvie, B. (2008). Is life unfair? What's next for juveniles after Roper v. Simmons. Baylor Law Review, 60, 293-313. 
Pifer, N. (2010). Is life the same as death?: Implications of Graham v. Florida, Roper v. Simmons, and Atkins v. Virginia on life without parole sentences for juvenile and mentally retarded offenders. Loyola of Los Angeles Law Review, 43, 1495-1532

Roper v. Simmons, 543, U.S. 551 (2005).

Steffensmeier, D., \& Demuth, S. (2006). Does gender modify the effects of race-ethnicity on criminal sentencing? Sentences for male and female White, Black, and Hispanic defendants. Journal of Quantitative Criminol, 22, 241-251. Doi: 10.1007/s10940-0069010-2.

Steffensmeier, D., Ulmer, J., \& Kramer, J. (1998). The interaction of race, gender, and age in criminal sentencing: The punishment cost of being young, Black, and male. Criminology, 36, 763-798.

Steinberg, L. (2007). Risk taking in adolescence: New perspectives from brain and behavioral science. Current Directions in Psychological Science, 16, 55-59.

Steinberg, L., Graham, S., O’Brien, L., Woolard, J., Cauffman, E., \& Banich, M. (2009). Age differences in future orientation and delay discounting. Child Development, 80, 28-44.

Steinberg, L., \& Scott, E. S. (2003). Less guilty by reason of adolescence: Developmental immaturity, diminished responsibility, and the juvenile death penalty. American Psychologist, 58, 1009-1018.

Thompson v. Oklahoma, 487 U.S. 815. (1988).

Trop v. Dulles, 356, U.S. 86. (1958).

United States Sentencing Commission (2010). 2010 Federal Sentencing Guidelines Manual \& Supplement. Retrieved from http://www.ussc.gov/Guidelines/2010_guidelines/ToC_PDF.cfm 
Vogel, B. L., \& Vogel, R. E. (2003). The age of death: Appraising public opinion of juvenile capital punishment. Journal of Criminal Justice, 31, 169-183. 


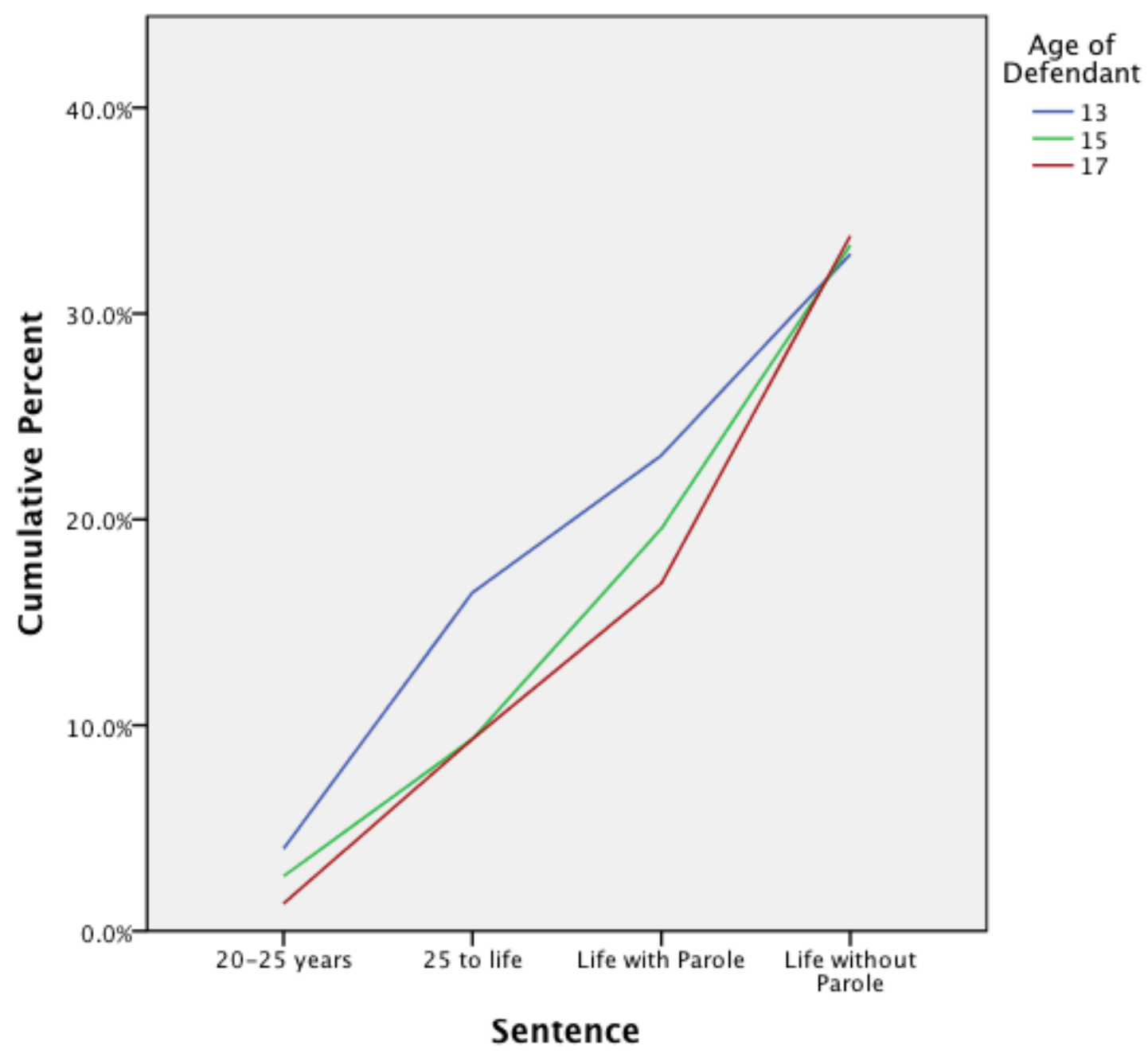

Figure 1. Cumulative percentages of defendant sentences categorized by age. The figure displays the cumulative distribution of the sentence as a function of the defendant's age. 


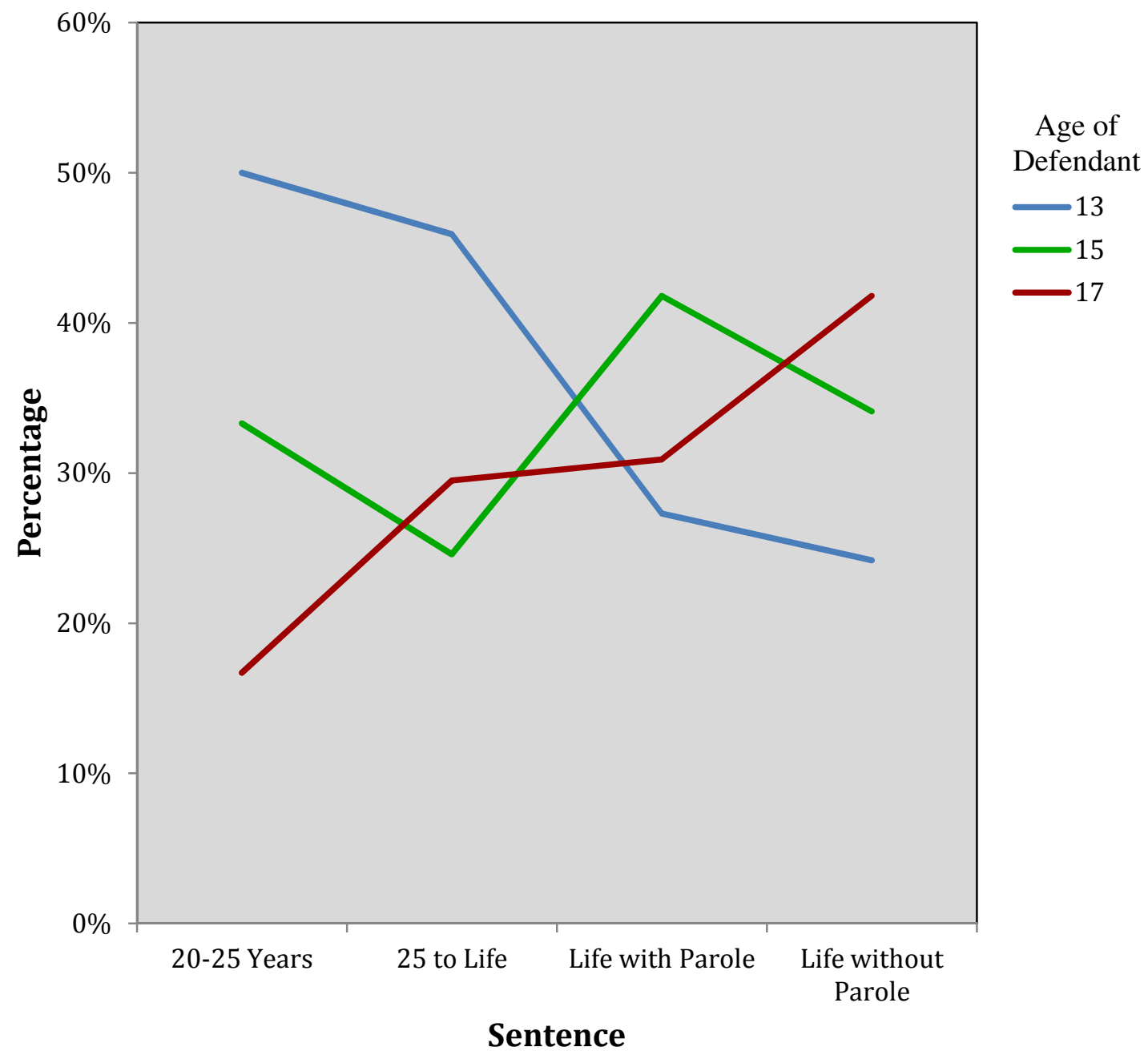

Figure 2. Percentages within sentence categories by age. The figure displays the percentage of defendants who were assigned to each sentence by defendant age. 
Table 1

Cross tabulation of defendant's age by final sentence

\begin{tabular}{cccccc}
\hline & \multicolumn{5}{c}{ Sentence } \\
\cline { 2 - 6 } $\begin{array}{c}\text { Age of } \\
\text { Defendant }\end{array}$ & 20-25 years & 25-Life & $\begin{array}{c}\text { Life with } \\
\text { Parole }\end{array}$ & $\begin{array}{c}\text { Life without } \\
\text { Parole }\end{array}$ & Total \\
\cline { 2 - 6 } 13 & $50 \%$ & $45.9 \%$ & $27.3 \%$ & $24.2 \%$ & $32.9 \%$ \\
15 & $33.3 \%$ & $24.6 \%$ & $41.8 \%$ & $34.1 \%$ & $33.3 \%$ \\
17 & $16.7 \%$ & $29.5 \%$ & $30.9 \%$ & $41.8 \%$ & $33.8 \%$ \\
$(\mathrm{~N})$ & $(18)$ & $(61)$ & $(55)$ & $(91)$ & $(225)$ \\
\hline
\end{tabular}

Note: Cells indicate \% of defendants given a specific sentence (column) were of a specific age (row). 


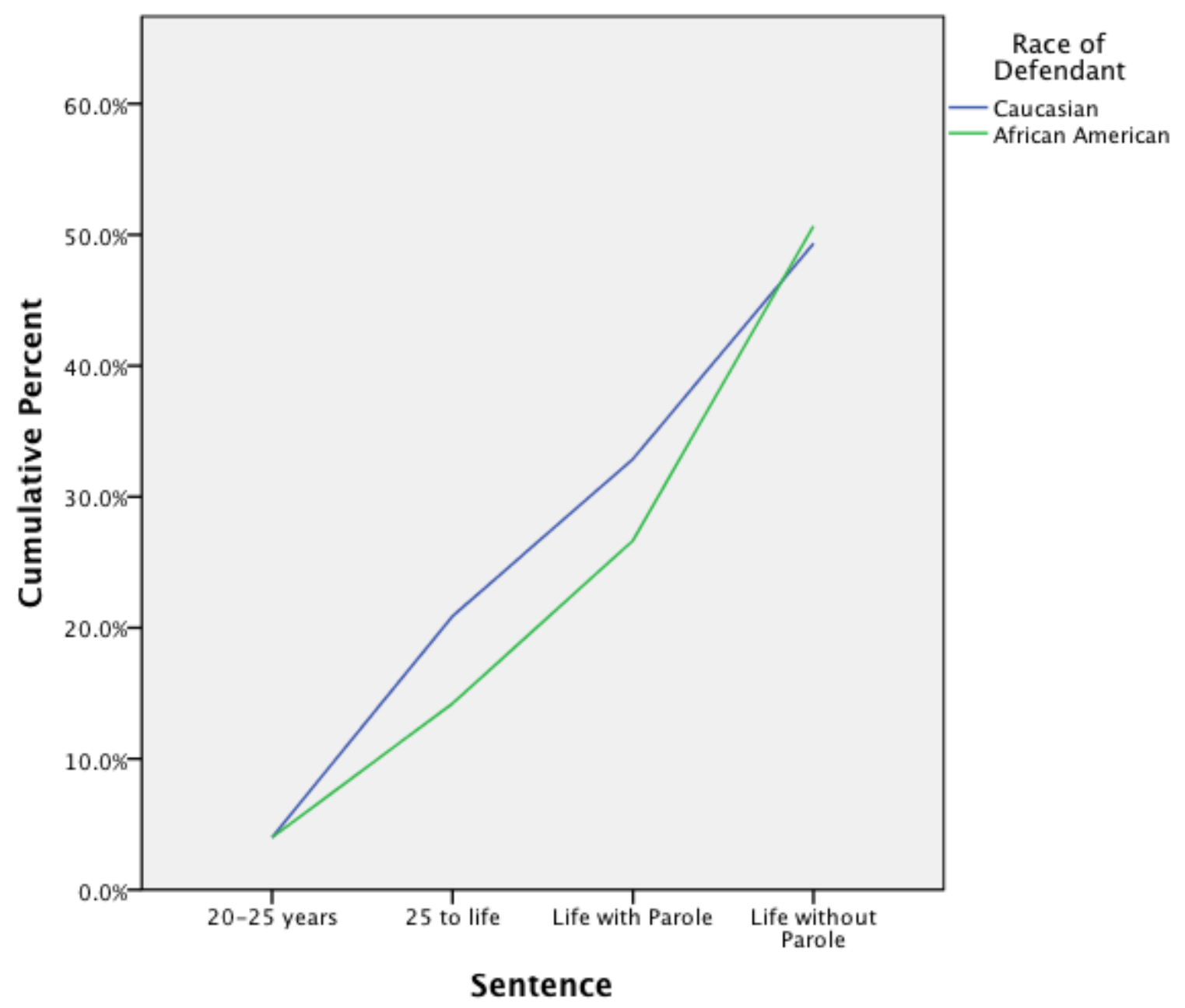

Figure 3. Cumulative percentages of defendant sentences categorized by race. The figure displays the cumulative distribution of the sentence as a function of the defendant's race. 


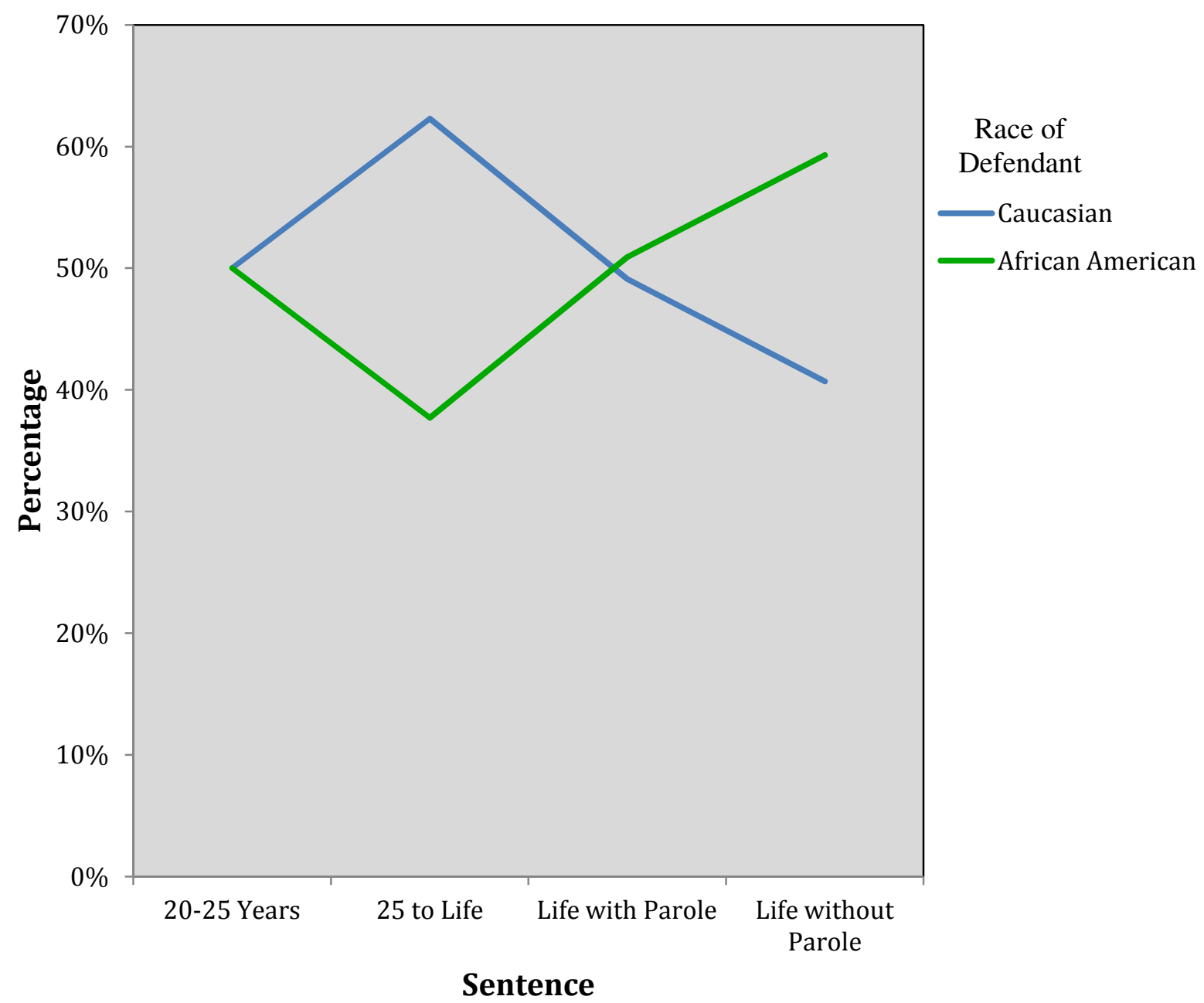

Figure 4. Percentages within sentence categories by race. The figure displays the percentage of defendants who were assigned to each sentence by defendant race. 
Table 2

Cross tabulation of defendant's race by final sentence

\begin{tabular}{cccccc}
\hline & \multicolumn{4}{c}{ Sentence } \\
\cline { 2 - 5 } $\begin{array}{c}\text { Race of } \\
\text { Defendant }\end{array}$ & $20-25$ years & $\begin{array}{c}25 \text { years } \\
\text { Life }\end{array}$ & $\begin{array}{c}\text { Life with } \\
\text { Parole }\end{array}$ & $\begin{array}{c}\text { Life without } \\
\text { Parole }\end{array}$ & Total \\
\hline Caucasian & $50 \%$ & $62.3 \%$ & $49.1 \%$ & $40.7 \%$ & $49.3 \%$ \\
$\begin{array}{c}\text { African } \\
\text { American }\end{array}$ & $50 \%$ & $37.7 \%$ & $50.9 \%$ & $59.3 \%$ & $50.7 \%$ \\
$(\mathrm{~N})$ & $(18)$ & $(61)$ & $(55)$ & $(91)$ & 225 \\
\hline
\end{tabular}

Note: Cells indicates \% of defendants given a specific sentence (column) were of a specific race (row). 


\title{
Appendix A
}

\author{
Informed Consent Form
}

Principal Investigators: $\quad$ Maria Annabel Mireles and Frank DiCataldo, Ph. D.

1. Purpose of the Study: To investigate judgments of potential jurors.

2. Procedures Experienced by Participants: Participants will be presented with a court case and asked to reach a verdict and determine sentencing based on that verdict. Following this, participants will be asked to fill out a brief questionnaire.

3. Confidentiality and Anonymity: Only the investigators listed above will have access to your responses, which will ensure your confidentiality. Additionally, your name will only be written on your consent form, which will be collected and maintained separately from your questionnaire. Thus, your responses will remain anonymous.

4. Your Rights: You have the right to decline participation without any penalties or prejudice because participation is strictly voluntary. Additionally, at any point in the study if you do not feel comfortable or no longer want to participate, you have the right to withdraw from the study without prejudice or penalty. You may also ask questions at any time during the course of the study and you may contact the primary investigator (whose name, email address and telephone number appear at the bottom of this form) at any time after you have participated in the study.

5. Compensation for Participation: Student participation will fulfill a research requirement.

6. Risks and Benefits of being a Participant: No physical, psychological, or emotional risks are associated with this study. At any time during your participation, you are allowed to withdraw from this study without facing any penalties. Potential benefits are that you might have a better understanding of how psychological research is conducted and how psychology and law interact.

More Information: After participation, please feel free to contact Maria Annabel Mireles by email at mmireles236@g.rwu.edu, or telephone 360-333-1889 or Frank Dicataldo, Ph. D. in FCAS 100, by e-mail at fdicataldo@rwu.edu, or by phone 401-254-7252 should you have any additional questions.

This certifies that I have given my full consent to participate

Print your name

in this study. I am at least 18 years of age or older. I have read this form and fully understand the content.

Participant's Signature

Date

This certifies that I have defined and informed the participant named above of all elements pertaining to this research study. 


\section{Appendix B}

Clark v. Pennsylvania (Based on Wilkins v. Missouri)

\section{Defendant: Daniel Clark}

Age: $(13,15,17)$

Race: (Caucasian, African American)

Charges: $1^{\text {st }}$ Degree Murder

\section{Case Details}

On October 26, 2009 Sarah Johnson was stabbed to death behind the sales counter of a convenience store co-owned by her husband and herself in Lancaster, Pennsylvania. Defendant Daniel Clark was (age) years old at the time of the alleged crime. According to police reports Clark planned to rob the store and kill the person working so as not to leave a witness. Held down by an accomplice, Clark stabbed Johnson causing her to fall to the floor. When the accomplice had difficulty accessing the cash register, Johnson spoke up to try to help leading Clark to stab her two more times in the chest. One of these wounds penetrated the heart. When Johnson began begging for her life, Clark stabbed her five more times in the neck, severing her carotid artery. After helping themselves to liquor, cigarettes, and approximately $\$ 450$ in cash, Clark and his accomplice left Johnson to die on the floor. 


\section{Appendix C}

Response Sheet

\section{Verdict}

On the count of $1^{\text {st }}$ Degree Murder, I find the defendant

_ Guilty _ _ Not Guilty

Please rate the level of confidence in your verdict

$\begin{array}{llllllllll}1 & 2 & 3 & 4 & 5 & 6 & 7 & 8 & 9 & 10\end{array}$

No Confidence Confident Completely Confident

\section{Sentencing}

Based on the above conviction, the defendant is hereby sentenced to:

L Life imprisonment without the possibility of parole

_ Life imprisonment with the possibility of parole

25 years to Life

20 to 25 years

No Sentence, the defendant is not guilty

Please rate the level of confidence in your choice of sentence

$\begin{array}{llllllllll}1 & 2 & 3 & 4 & 5 & 6 & 7 & 8 & 9 & 10\end{array}$

No Confidence Confident Completely Confident 


\section{Appendix D}

Demographic Questionnaire

Please circle one of the following:

Age: $18 \quad 19 \quad 20 \quad 21 \quad 22$ Other:

Gender: Male Female

Race: Caucasian

Hispanic

African American

Asian

Native American

Pacific Islander

Other:

Have you ever been called to serve on a jury?

Yes No

Have you ever served on a jury?

Yes No 


\section{Debriefing statement}

Thank you for your participation today. The current study is investigating whether age and race are predictive factors in adolescents receiving sentences of life without the possibility of parole. The researcher asks that you please not discuss the purpose of this study with others so as not to compromise future data collection. If you have any questions feel free to ask or to e-mail the researchers at mmireles236@g.rwu.edu or fdicataldo@ rwu.edu. 